\title{
Article \\ Relationship between Training Factors and Injuries in
Stand-Up Paddleboarding Athletes
}

\author{
Arkaitz Castañeda-Babarro ${ }^{1,2}{ }^{\oplus}$, Julio Calleja-González ${ }^{3}\left(\mathbb{D}\right.$, Aitor Viribay ${ }^{4}$, Diego Fernández-Lázaro ${ }^{5,6} \mathbb{( D}^{\text {, }}$ \\ Patxi León-Guereño ${ }^{1}\left(\mathbb{D}\right.$ and Juan Mielgo-Ayuso ${ }^{7,8, *}$
}

\section{check for}

updates

Citation: Castañeda-Babarro, A. Calleja-González, J.; Viribay, A.; Fernández-Lázaro, D.; León-Guereño, P.; Mielgo-Ayuso, J. Relationship between Training Factors and Injuries in Stand-Up Paddleboarding Athletes. Int. J. Environ. Res. Public Health 2021, 18, 880. https://doi.org/10.3390/ ijerph18030880

Academic Editor: Filipe Manuel Clemente; Daniel Castillo; Javier Raya-González

Received: 17 December 2020

Accepted: 18 January 2021

Published: 20 January 2021

Publisher's Note: MDPI stays neutral with regard to jurisdictional claims in published maps and institutional affiliations.

Copyright: (c) 2021 by the authors. Licensee MDPI, Basel, Switzerland This article is an open access article distributed under the terms and conditions of the Creative Commons Attribution (CC BY) license (https:/ creativecommons.org/licenses/by/ $4.0 /)$
1 Health, Physical Activity and Sports Science Laboratory, Department of Physical Activity and Sports, Faculty of Psychology and Education, University of Deusto, 48007 Bizkaia, Spain; arkaitz.castaneda@deusto.es (A.C.-B.); patxi.leon@deusto.es (P.L.-G.)

2 Physiotherapy Department, Institute of Biomedicine (IBIOMED), Campus of Vegazana, University of Leon, 24071 Leon, Spain

3 Department of Physical Education and Sport, Faculty of Education and Sport, University of the Basque Country (UPV /EHU), 01007 Vitoria, Spain; julio.calleja.gonzalez@gmail.com

4 Glut4Science, Physiology, Nutrition and Sport, 01004 Vitoria-Gasteiz, Spain; aitor@glut4science.com

5 Department of Cellular Biology, Histology and Pharmacology, Faculty of Health Sciences, Campus of Soria, University of Valladolid, 42003 Soria, Spain; diego.fernandez.lazaro@uva.es

6 Neurobiology Research Group, Faculty of Medicine, University of Valladolid, 47005 Valladolid, Spain

7 Department of Health Sciences, Faculty of Health Sciences, University of Burgos, 09001 Burgos, Spain

8 ImFINE Research Group, Department of Health and Human Performance, Faculty of Physical Activity and Sport Sciences-INEF, Polytechnic University of Madrid, 28040 Madrid, Spain

* Correspondence: jfmielgo@ubu.es

Abstract: Stand-up paddleboarding (SUP) is an increasingly popular sport but, as in other sports, there is an injury ratio associated with practicing it. In other types of sport, some factors have been linked to the likelihood of suffering an injury, among which stretching, core training and resistance training may be considered the most significant. Therefore, the main aim of this study was to identify the training factors that could influence injuries suffered by participants in international SUP competitions. Ninety-seven questionnaires were collected from paddlers who participated in an international SUP circuit, with epidemiological data being gathered about injuries and different questions related to the training undertaken. A multi-factor ANOVA test was used to identify the factors which influence the state of injury. Results showed that almost $60 \%$ of injuries occurred in the arms or in the upper thoracic region, around $65 \%$ of which were in tendons or muscles and, in almost half of cases, were related to overuse. Likewise, the results showed that athletes with injury performed fewer resistance training sessions per week $(p=0.028)$, over fewer months per year $(p=0.001)$, more weekly training sessions $(p=0.004)$ and, lastly, a greater volume of weekly training $(p=0.003)$ than athletes without injury. Moreover, the most important training factors that reduce the likelihood of suffering an injury were taken into account-in. particular, resistance training alone $(p=0.011)$ or together with CORE training $(p=0.006)$ or stretching $(p=0.012)$, and the dominant side of paddling ( $p=0.032$ ). In conclusion, resistance training would seem to reduce the likelihood of injury among SUP practitioners, and such benefits could be obtained by resistance training alone or in combination with CORE training or stretching.

Keywords: stand-up paddleboarding; SUP; injury; prevention; resistance training

\section{Introduction}

Stand-up paddleboarding (SUP) is an increasingly popular water sport, born from surfing with modern roots in Hawaii [1]. SUP paddleboarders stand on boards that float on the water and use a paddle to propel themselves through the water. This type of sport requires good balance and great strength in the trunk muscles [2], as well as a well-developed aerobic capacity [3]. However, its practice (like other water sports) is not 
devoid of the risk of injury [4,5]. In this regard, the most common pathologies affecting SUP paddlers tend to be those linked to the shoulders, lower back and wrist $[6,7]$. In particular, $31-32.9 \%$ of paddlers had reported shoulder pain [6,7], while $25-33 \%$ also had back pain $[8,9]$. For that reason, it has been suggested that risk of injury may be related to a number of factors including: uneven surface conditions [8,9], poor technique with unusual movement patterns and force-profile asymmetry [10-13], the hours spent performing SUP [6] and the repetitive nature of paddling [14,15]. In addition, other factors previously identified in other types of sport might also influence the likelihood of injury to the SUP paddle boarder. Some of these variables are: stretching [16-18] or core strengthening [19-21] and resistance training (RT) [22-25].

There have been studies conducted on the lack of flexibility regarding the greater likelihood of injury in hamstrings [26]. However, it might be the stretching technique that increases flexibility beyond that required for sport-specific movements which causes these types of injury [17]. Given the different demands and ranges of motion, the vast majority of studies do not most likely differentiate between different types of injury, and so it is difficult to ascertain the relationship between flexibility and the likelihood of injury [18]. However, as far as CORE training is concerned, it would seem that literature is more in agreement, since following 8 weeks of CORE training, improvements in postural control and quality of movement have been reported in university athletes [19], or improvements in reaction to jumps in female athletes following 6 weeks of CORE training [20], which could have a real impact on injury prevention, although studies are still required to further clarify this statement.

With regard to RT, it has been shown that it is the only modifiable risk factor that contributes significantly to the likelihood of suffering a sports injury [27]. It has been known for years that RT can help prevent injuries due to overuse such as swimmers' shoulders or tennis elbows [28]. In this regard, RT would appear to have a direct relationship with the probability of injury in active people, it being demonstrated that 4 weeks of resistance training reduced the possibility of injury in hamstrings [29] and, in the case of the military, a 14-week program with 4 daily resistance training exercises involving concentric and functional eccentric contractions of the hip and knee extensors was applied to prevent anterior knee pain in military recruits, with positive effects being obtained [30]. In types of sport such as soccer, it was demonstrated how 12 weeks of RT significantly reduced the number of injuries in young players [31], or in running, for which resistance training is recommended to prevent future injuries [32], enabling the athlete to perform successfully [33]. It should be noted that the effect of this type of training is not only valid in reducing the likelihood of injury, but also in reducing its severity. To this end, a study was carried out on high school athletes, in which it was shown that athletes who had undertaken RT suffered fewer injuries ( $26.2 \%$ vs. $72.4 \%)$, and also less time was lost over the injury rehabilitation period (2.02 days vs. 4.82 days) [34]. Unfortunately, no previous evidence has been reported about the influence of training factors on injuries suffered in SUP, to the best of the author's knowledge.

For that reason, the main aim of this study focused on identifying any training factors that could influence injuries suffered by participants in international SUP competitions. We conducted an online survey, and then related this data to different variables associated with training, especially RT. The information gathered in the survey would go on to form the basis for prevention strategies in SUP sports injuries, based on previous references $[6,7]$.

\section{Methods}

\subsection{Participants}

The research was conducted in the form of a retrospective observational cohort study. All athletes who competed in international race circuit races (Eurotour) were offered the chance to participate in this online test (2019). One hundred and six participants started the survey, nine of whom did not answer the injury section, leaving 97 participants $(77.3 \%$ male and $22.7 \%$ female) that were finally included in the injury analysis ( $38.06 \pm 11.72$ years). 
Participation was worldwide, with the majority from Spain $(69.2 \%)$, followed by the rest of Europe (24.5\%), United States (4.2\%), Africa and Australia (2.1\%).

Ethics were approved by the University of Deusto Research Ethics Committee (ref: ETK-13/18-19), designed in accordance with the Declaration of Helsinki $[35,36]$. Participants received all the information detailing the study aims in advance. Their rights were preserved, with voluntary participation being requested, and the chance to withdraw at any moment being provided. Information regarding the purpose, procedures and confidentiality of the study was provided, and informed consent obtained from all participants.

\subsection{Experimental Trials}

The survey consisted of four sections: (I) introduction and informed consent, (II) demographics and participation, (III) training and competition, and (IV) injuries. Section I provided background information on the purpose of the study and electronic informed consent, with participants being unable to access the survey unless they provided such consent. Section II involved demographic and SUP participation questions, namely questions regarding age, sex, height, and body mass. Section III referred to questions related to training routines (contents of the training: flexibility, resistance, and strength), and the amount performed by participants in the course of such training). Section IV involved questions about SUP injuries and their epidemiology. The participants were instructed to provide information specifically regarding SUP injuries suffered over the last year, and in an attempt to gather data about multiple injuries on the same part of the body, they were able to provide information about more than one injury to the same part.

\subsection{Procedure}

An online Ad-hoc specific survey was specifically used to determine the epidemiology of injuries suffered by participants in international SUP competitions, via an online survey, with this data being linked to different variables attached to training, especially RT and free-text responses. The authors designed the first draft of the survey, and a pilot test was performed by two members not included in the study who volunteered to participate. This survey had been used in previously published surveys on injuries and $[6,7]$ was available in both Spanish (Supplementary Materials) and English (Supplementary Materials) from 20 April 2019 to 15 July 2019, when the participants gave their responses. It comprises the six sections described in the following paragraph and took a maximum time of $15 \mathrm{~min}$ to be completed. An email was sent to the participants of an international SUP race circuit, in which they were informed of the objectives set out by the study and asked to participate. The questionnaire was sent out twice and participants were allowed to respond to it over a period of three months.

\subsection{Statistical Analysis}

The results were shown as frequencies and \% of cases. Kolmogorov-Smirnov tests were carried out to test the normality of the studied continuous variables $(n>50)$. and the Levene test was used to check the homoscedasticity of the differences in variance of different descriptive and/or training data between male and female, assessed via a one-way ANOVA test with the injury as a mixed factor. Moreover, the multi-factor ANOVA test was used to identify those factors which influence the state of injury. For their part, effect sizes were calculated using partial square eta $\left(\eta^{2} \mathrm{p}\right)$, and interpreted according to the one indicating that there is no effect if $0 \leq \eta^{2} p<0.05$; minimal effect if $0.05 \leq \eta^{2} p<0.26$; moderate effect if $0.26 \leq \eta^{2} p<0.64$; and a major effect if $\eta^{2} p \geq 0.64$ [37]. Post hoc statistical power was calculated for paired T-test, while statistical. analysis was completed using SPSS Statistics version 24.0 (SPSS: An IBM Company, IBM Corporation, Armonk, NY, USA). Lastly, statistical significance was designated in cases where $p<0.05$. 


\section{Results}

The 97 valid responses received were distributed among participants who had suffered some kind of injury and those who had not suffered any injury when practicing SUP. Demographic and body composition data were related to the likelihood of suffering an injury, and both the number of years' practice of the activity and the number of annual or international competitions performed were positively related (Table 1).

Table 1. Demographic and Body composition data of the participants based on state of injury.

\begin{tabular}{cccccc}
\hline & No $(\boldsymbol{n}=\mathbf{3 6})$ & Yes $(\boldsymbol{n}=\mathbf{6 1})$ & $\boldsymbol{p}$ & $\boldsymbol{\eta}^{\mathbf{2}} \mathbf{p}$ & Post Hoc Power \\
\hline Age (Year) & $38.31 \pm 13.29$ & $37.95 \pm 11.09$ & 0.897 & 0.000 & 0.050 \\
\hline Body mass $(\mathrm{Kg})$ & $75.77 \pm 14.60$ & $72.85 \pm 12.72$ & 0.352 & 0.010 & 0.135 \\
\hline Height $(\mathrm{m})$ & $175.36 \pm 10.52$ & $174.59 \pm 7.71$ & 0.679 & 0.002 & 0.070 \\
\hline Body Mass Index & $24.30 \pm 3.78$ & $23.79 \pm 3.08$ & 0.471 & 0.005 & 0.110 \\
\hline Practice of sup (year) & $1.54 \pm 0.65$ & $1.82 \pm 0.53$ & 0.038 & 0.050 & 0.551 \\
\hline Competitions per year & $2.54 \pm 0.95$ & $3.30 \pm 0.97$ & 0.001 & 0.116 & 0.957 \\
\hline International competitions & $1.92 \pm 0.98$ & $2.59 \pm 0.74$ & 0.001 & 0.125 & 0.969
\end{tabular}

Data expressed as mean \pm standard deviation. $p$-value: significant differences according to state of injury by one ANOVA factor. No: Has not suffered any injury, Yes: Has suffered some injury.

In terms of the epidemiology of recorded lesions (Table 2), almost $60 \%$ occurred in the arms or in the upper thoracic region, revealing which parts of the body are most vulnerable during SUP. Regarding diagnosis, approximately $65 \%$ of injuries were in tendons or muscles and almost half of cases were related to overuse.

Table 2. Characteristics of recorded injuries.

\begin{tabular}{cccc}
\hline & & \multicolumn{2}{c}{ Total $(\boldsymbol{n = 6 1 )}$} \\
\hline & & $n$ & $\mathbf{\%}$ \\
\hline \multirow{3}{*}{ Anatomical Area } & Head & 2 & 3.3 \\
& Arm & 15 & 24.6 \\
& Upper thoracic region & 21 & 34.4 \\
& Back & 11 & 18.0 \\
& Lower Body & 12 & 19.7 \\
\hline \multirow{2}{*}{ Diagnosis } & Tendinitis & 21 & 34.4 \\
& Irritation & 2 & 3.3 \\
& Subluxation or sprain & 4 & 6.6 \\
& Concussion & 2 & 3.3 \\
& Fracture-muscle damage & 11 & 18.0 \\
& Luxation & 2 & 3.3 \\
& Muscle Contracture & 8 & 13.1 \\
& Superficial Wound & 3 & 4.9 \\
Type of Injury & Others & 8 & 13.1 \\
\hline \multirow{2}{*}{} & New injury & 50 & 82.0 \\
& Relapse of Injury & 11 & 18.0 \\
\hline
\end{tabular}

Of all the variables consulted related to training, four were significantly different depending on injured or non-injured groups of participants (Table 3): resistance training sessions per week, months per year spent resistance training, number of weekly training sessions and volume of weekly training. Both the volume of training performed weekly (expressed in sessions or total volume) and the amount of resistance training performed (expressed in weekly sessions or months per year conducted) would appear to be the most important variables to take into consideration in order to prevent injuries. 
Table 3. Training characteristics of participants based on state of injury.

\begin{tabular}{cccccc}
\hline & No $(n=36)$ & Yes $(\boldsymbol{n}=\mathbf{6 1})$ & $\boldsymbol{p}$ & $\boldsymbol{\eta}^{\mathbf{2}} \mathbf{p}$ & $\begin{array}{c}\text { Post Hoc } \\
\text { Power }\end{array}$ \\
\hline Resistance sessions per week (day) & $1.85 \pm 1.46$ & $1.11 \pm 1.37$ & 0.028 & 0.056 & 0.600 \\
Months per year of resistance training & $8.23 \pm 4.68$ & $4.11 \pm 4.89$ & $<0.001$ & 0.135 & 0.950 \\
Training amount (days per week) & $3.00 \pm 1.39$ & $4.07 \pm 1.60$ & 0.004 & 0.093 & 0.831 \\
$\quad$ Training sessions per day & $1.15 \pm 0.46$ & $1.28 \pm 0.49$ & 0.271 & 0.014 & 0.195 \\
Average session duration (hour) & $1.42 \pm 0.39$ & $1.59 \pm 0.39$ & 0.073 & 0.037 & 0.435 \\
Weekly training volume (hour) & $4.81 \pm 2.87$ & $8.62 \pm 5.96$ & 0.003 & 0.102 & 0.869 \\
Maximum session volume (hour) & $2.96 \pm 1.22$ & $3.51 \pm 1.64$ & 0.130 & 0.027 & 0.327 \\
$\quad \begin{array}{c}\text { Training for another sport } \\
\text { (days per week) }\end{array}$ & $2.55 \pm 1.30$ & $2.76 \pm 1.14$ & 0.488 & 0.007 & 0.106 \\
$\quad \begin{array}{c}\text { Core training (days per week) } \\
\text { Flexibility training (days per week) }\end{array}$ & $2.40 \pm 1.54$ & $2.53 \pm 1.50$ & 0.763 & 0.002 & 0.060 \\
$\quad \begin{array}{c}\text { Resistance training + core } \\
\text { (days per week) }\end{array}$ & $4.00 \pm 2.34$ & $3.76 \pm 2.22$ & 0.681 & 0.003 & 0.069 \\
$\begin{array}{c}\text { Resistance training + core + flexibility } \\
\text { (days per week) }\end{array}$ & $8.28 \pm 4.52$ & $7.58 \pm 3.67$ & 0.461 & 0.007 & 0.113 \\
$\begin{array}{c}\text { Resistance training + flexibility } \\
\text { (days per week) }\end{array}$ & $4.25 \pm 2.52$ & $3.96 \pm 2.19$ & 0.611 & 0.003 & 0.080
\end{tabular}

Data expressed as mean \pm standard deviation. $p$-value: significant differences according to state of injury by one ANOVA factor. No: Has not suffered any injury, Yes: Has suffered some injury.

Related to the above, the following (Table 4) shows the differences in various variables among participants who suffered an injury and those who had not, although variables such as gender or practicing a sport other than SUP would not seem to affect the likelihood of suffering an injury. RT (alone or together with CORE training or stretching) or the dominant side of paddling are the variable that gave rise to differences in the likelihood of suffering an injury while practicing SUP $(p<0.05)$.

Table 4. Injured participant's characteristics.

\begin{tabular}{|c|c|c|c|c|c|c|}
\hline & & No & Yes & $p$ & $\eta^{2} p$ & $\begin{array}{l}\text { Post Hoc } \\
\text { Power }\end{array}$ \\
\hline Gender & $\begin{array}{l}\text { Male } \\
\text { Female }\end{array}$ & $\begin{array}{c}24.1 \% \\
5.7 \%\end{array}$ & $\begin{array}{l}51.7 \% \\
18.4 \%\end{array}$ & 0.547 & 0.004 & 0.092 \\
\hline Dominant side & $\begin{array}{l}\text { Right } \\
\text { Left } \\
\text { Both }\end{array}$ & $\begin{array}{c}9.1 \% \\
11.5 \% \\
9.2 \% \\
\end{array}$ & $\begin{array}{l}37.9 \% \\
21.8 \% \\
10.3 \%\end{array}$ & 0.032 & 0.054 & 0.577 \\
\hline Practicing another Sport & $\begin{array}{l}\text { Yes } \\
\text { No }\end{array}$ & $\begin{array}{c}25.3 \% \\
4.6 \%\end{array}$ & $\begin{array}{l}50.6 \% \\
19.5 \%\end{array}$ & 0.250 & 0.016 & 0.209 \\
\hline Resistance training & $\begin{array}{l}\text { Yes } \\
\text { No }\end{array}$ & $\begin{array}{l}23 \% \\
6.9 \% \\
\end{array}$ & $\begin{array}{l}32.2 \% \\
37.9 \% \\
\end{array}$ & 0.011 & 0.075 & 0.735 \\
\hline Core training & $\begin{array}{l}\text { Yes } \\
\text { No }\end{array}$ & $\begin{array}{l}23 \% \\
6.9 \%\end{array}$ & $\begin{array}{l}39.1 \% \\
31.0 \%\end{array}$ & 0.081 & 0.036 & 0.415 \\
\hline Stretching & $\begin{array}{c}\text { Yes } \\
\text { No } \\
\text { Sometimes }\end{array}$ & $\begin{array}{c}14.9 \% \\
3.4 \% \\
11.5 \% \\
\end{array}$ & $\begin{array}{l}32.2 \% \\
11.5 \% \\
26.4 \% \\
\end{array}$ & 0.723 & 0.001 & 0.064 \\
\hline $\begin{array}{l}\text { Other sport }+ \text { Resistance } \\
\text { training }\end{array}$ & $\begin{array}{l}\text { Yes } \\
\text { No }\end{array}$ & $\begin{array}{c}2.3 \% \\
27.6 \%\end{array}$ & $\begin{array}{l}4.6 \% \\
65.5 \%\end{array}$ & 0.814 & 0.001 & 0.056 \\
\hline $\begin{array}{l}\text { Other sport + Resistance } \\
\text { training + Stretching }\end{array}$ & $\begin{array}{l}\text { Yes } \\
\text { No }\end{array}$ & $\begin{array}{l}2.3 \% \\
27.6 \%\end{array}$ & $\begin{array}{l}3.4 \% \\
66.7 \%\end{array}$ & 0.584 & 0.004 & 0.084 \\
\hline
\end{tabular}


Table 4. Cont.

\begin{tabular}{|c|c|c|c|c|c|c|}
\hline & & No & Yes & $p$ & $\eta^{2} p$ & $\begin{array}{c}\text { Post Hoc } \\
\text { Power }\end{array}$ \\
\hline $\begin{array}{l}\text { Other sport + Resistance } \\
\text { training + Stretching + Core }\end{array}$ & $\begin{array}{l}\text { Yes } \\
\text { No }\end{array}$ & $\begin{array}{c}2.3 \% \\
27.6 \%\end{array}$ & $\begin{array}{l}2.3 \% \\
68.8 \%\end{array}$ & 0.351 & 0.010 & 0.153 \\
\hline $\begin{array}{l}\text { Other sport }+ \text { Resistance } \\
\text { training + Core }\end{array}$ & $\begin{array}{l}\text { Yes } \\
\text { No }\end{array}$ & $\begin{array}{c}2.3 \% \\
27.6 \%\end{array}$ & $\begin{array}{l}3.4 \% \\
66.7 \%\end{array}$ & 0.584 & 0.004 & 0.084 \\
\hline $\begin{array}{l}\text { Resistance training + } \\
\text { Stretching }\end{array}$ & $\begin{array}{l}\text { Yes } \\
\text { No }\end{array}$ & $\begin{array}{l}21.8 \% \\
8.0 \%\end{array}$ & $\begin{array}{l}27.6 \% \\
42.5 \%\end{array}$ & 0.006 & 0.088 & 0.804 \\
\hline Resistance training + Core & $\begin{array}{l}\text { Yes } \\
\text { No }\end{array}$ & $\begin{array}{l}19.5 \% \\
10.3 \%\end{array}$ & $\begin{array}{l}24.1 \% \\
46.0 \%\end{array}$ & 0.012 & 0.074 & 0.723 \\
\hline Cooling Down & $\begin{array}{c}\text { Yes } \\
\text { No } \\
\text { Sometimes }\end{array}$ & $\begin{array}{c}13.8 \% \\
4.6 \% \\
10.3 \%\end{array}$ & $\begin{array}{l}34.5 \% \\
16.1 \% \\
19.5 \%\end{array}$ & 0.657 & 0.02 & 0.073 \\
\hline
\end{tabular}

p-value: significant differences between injured state by multifactorial ANOVA. No: Has not suffered any injury, Yes: Has suffered some injury.

\section{Discussion}

The main aim of the present study was to establish the training factors which influence injuries in international SUP competitions. The main finding of this research showed that $\mathrm{RT}$, regardless of the number of weekly sessions, volume of training or the dominant side of paddling, was seen to have a significant relationship with the likelihood of injury in SUP practitioners.

To the best of our knowledge, scarce scientific evidence related to injury has been published in the scientific literature about SUP. As for the type of injury and recorded injuries described in our study, these do not vary much from the data obtained by Furness et al. [6]. In our case, $59 \%$ of recorded injuries were in the upper thoracic region $(34.4 \%)$ or in the arms $(24.6 \%)$, while in the data recorded by Furness et al. these areas were also the most affected with $44.5 \%$. In terms of the type of injury, in $52.5 \%$ of recorded data this occurred in the tendon or muscle, while in the case of Furness et al. [6] it was $50.4 \%$ with similar percentages.

As far as flexibility training is concerned, no significant relationship was found in terms of a reduction in injuries. The literature on the subject is very confusing regarding this hot topic, given that some studies support the idea that flexibility work can reduce the likelihood of injury [38,39], or a limitation in it can increase the risk of injury [40]. However, it depends on the type of training system used, type of sport practiced or other variables [18]. Conversely, in some studies, the decrease in flexibility is associated with greater economy in terms of running [41]. Other scientific articles claim that an increase in flexibility beyond that necessary for the type of sport involved can cause injuries [17] ... and so no conclusive statements can be made about the relationship between flexibility and the likelihood of injury [18]; the fact that no relationship was found may be due to the type of flexibility training performed by each athlete and the different types of injury recorded. Therefore, further research is necessary in this field.

The literature is scarce when it comes to CORE training and reduction in the likelihood of injury. Improvements have been described following 8 weeks of CORE training in movement patterns with college athletes [19], in the jumping pattern of dancers after 6 weeks of CORE training [20] and in firefighters, with a $42 \%$ reduction in CORE training injuries [21]. This difference between the data obtained in the study and existing literature may be due to the fact that SUP is a sport that is very demanding in terms of balance [2]. Therefore, it is assumed that SUP practitioners will make a major effort to stabilize muscles, including CORE. For that reason, specific work on this may not give rise to improvements.

The fact that those who are least injured train almost twice as many months a year in RT and undertake almost twice as many weekly RT sessions as those who are most injured highlights the importance not only of RT, but of training in it for a sufficient of time 
and with a sufficient weekly load. In this regard, there are studies [42] that show that a preventive program of only $10-15$ min' duration is enough to achieve a $45 \%$ reduction in the likelihood of injury, although this will of course also depend on different factors such as: the characteristics of the participant; the type of injury training program carried out or other types of variable. There is a trend towards increasingly injuries being reduced in those studies with a longer intervention phase compared to others with shorter intervention periods [43-46]. There are studies that have recorded improvements in strength with intervention programs of only $2-4$ weeks' duration [47-49], with this increase most likely caused by neuromuscular and connective tissue adaptations [50], rather than an increase in muscle. As for the reduction in injuries, improvements have been reported in intervention studies of only 4 weeks' duration [51,52]. Having said this, it is likely that the participants interviewed underwent too little training load to be sufficiently adapted, although we do not know what type of work is the most suitable.

It should be noted that the vast majority of research conducted so far, in which an injury prevention program is applied so as to research into its effect on a population, does not distinguish between different types of injury and types of RT [53]. This is the main reason why it is difficult to associate one type of RT with the prevention of a particular injury. While it is clear that RT plays an important role in injury prevention and rehabilitation [54], it is also clear that there is no single optimal RT program for all sports yet to our knowledge. Thus, an appropriate training program should take into account the following variables: characteristics of the participants, the main aims of the program, and the type of injury to be prevented, as well as the muscle imbalances between agonists and antagonists [55]. Some researchers stress the importance of evaluating muscle imbalances between agonistantagonists, as well as the same muscle groups at different extremities, with the aim of detecting athletes with a greater predisposition to injury [28].

It would seem that RT improves the capacity of the muscles to work for long periods of time, as well as increasing the elasticity of the tendon-aponeurosis structures [56], given that heavy loads lead to greater neuromuscular improvements. In the case of programs aimed at strengthening connective tissue, such as ligaments, eccentric activations would seem to be the most appropriate [57] because they generate more tension with less metabolic stress [58]. However, this type of training would not seem to have the same potential for the tendons, given that the collagen metabolism appears not to be affected by such activations [57].

In muscles, a reduction in muscle mass is a factor that increases the likelihood of injury and RT is an effective way of avoiding this [59]. Adaptations in the muscle occur at different stages, and at the beginning of the program there are rapid improvements in strength due to neuromuscular adaptations, followed by a slow progression as the muscle increases its cross-sectional area [60,61]. The neuromuscular adaptations observed are mainly: acquisition of a motor function by the nervous system, increased muscle activation and improved synchronization of motor units and improved intramuscular coordination [62]. In terms of hypertrophy, the main adaptation involves an increase in the cross-sectional area of the fibers, as well as an increase in the number of sarcomeres [63].

In addition to these adaptations, bone adaptations also occur as a result of RT training, mainly improvements in bone density and, therefore, in bone strength, and it would seem that RT training is one of the most osteogenic effects [59]. In the case of connective tissue, however, adaptations would seem to occur in both the increase in size and strength of these tissues [54,57], the increase in size appearing to be the result of the increase in collagen, with the latter being proportional to the increase in muscle. Thus, everything points to the fact that the increase in muscle mass corresponds to the increase in size and strength of the connective tissue [59]. In addition, researchers have shown that injured tendons and ligaments recover faster when athletes undertake RT [56]. The influence of genetics and nutrients on RT adaptations in each individual [64-67], based on anatomical variability, should therefore not be overlooked. 
However, the risks attached to RT must be considered, as well as the risk of training with loads or inappropriate volumes for strength training, although most scientific literature indicates that RT is safer than many other types of activity, especially when performed under supervision [34]. Some studies in fact point out the danger of RT [68], insofar as performing. volumes and intensities greater than the subject can assimilate could increase the risk of injury [69]. In addition, RT with heavy loads prior to some activities could be harmful and increase the risk of injury due to the fatigue it leaves in the tissues [70]. This only reinforces ideas about the importance of personalized training and proper application between load and recovery [71], as well as the gradual conditioning of the tissues [30].

On the other hand, although RT improvements in performance [72] and health [73] are well known, the effect and mechanisms of RT on injury prevention have not yet been well documented [55]. Having said this, it is impossible to avoid injuries completely, although there would seem to be ways of reducing the risk and severity of injuries by progressively increasing the tensile strength of the tissue [55]. However, the results obtained from this study failed to find any improvements in CORE and flexibility training, bearing in mind the existing confusing literature and the need for more studies that delve deeper into the different training systems of each content as well as the different injuries. Therefore, we cannot recommend training in them, especially given their low risk and the low volume or workload needed to obtain improvements. For this reason, a multi-component prevention training routine is advocated which would seem to be the most suitable way of preventing both the amount and variety of injuries [74], albeit always with RT as the main component.

Lastly, it is important to take into account the importance of dominance of one side or the other when paddling in view of the likelihood of suffering an injury. As in the case of other types of such activity, there are studies that defend the idea that asymmetries increase the likelihood of suffering an injury [75], or even decompensation deriving from unilateral daily activities [76]. In the data reported by paddlers, the dominance of one side of the paddle would also seem to be linked to the likelihood of suffering an injury. This may be due to the fact that when practicing SUP, even if paddlers are paddling on both sides of the board alternately [2], experienced paddlers, such as those subject to study here, are able to paddle by keeping the board in the right direction. Thus, the main load is supported by the paddler's dominant side.

\section{Limitations and Strength and Future Lines of Research}

Some limitations in the study should be recognized. The main one is the free interpretation that participants need to make in defining the concepts of flexibility, core and resistance training. All concepts encompass different training systems and while some may be beneficial, others may have no effect or may even have a negative effect on the likelihood of injury. On the other hand, the study sample is small, despite considering the type of sport that is SUP and the number of participants who usually take part in this type of competition. Besides, the sample has a greater significance. Based on this first approach, we can recommend training program strategies in order to reduce the injury rate when athletes practice or compete in SUP.

Further studies, like the present one, are needed in other countries, as educational backgrounds differ from country to country and athletes' preferences may vary according to their gender, age or ethnicity and culture, with different possibilities replicating the methodology used in the present study arising. The use of cross-sectional vs. longitudinal surveys may offer the potential for further chances for scrutiny in parallel future studies. However, this approach may miss some relevant information regarding the motivation behind coaches and practitioners.

\section{Conclusions}

In summary, resistance training, alone, with CORE or stretching, has been shown to play a key role in the prevention of injuries in SUP among athletes who have competed in international circuit races. Thus, unlike CORE and flexibility training, resistance training 
reduces the likelihood of injury among SUP competitors. Moreover, the number of weekly sessions, as well as the volume of training, would seem to be related to injury in SUP international athletes. On the other hand, over $50 \%$ of registered injuries are located in the arms or in the upper thoracic region.

\section{Practical Applications}

In this study we tried to ascertain the relationship between flexibility training, CORE and RT with the likelihood of injury in SUP. RT has tended to be associated with a reduction in recorded injuries, although this has not been the case with CORE or flexibility training. This concept may help coaches and team physician members to improve the design of their athletes' routines, and hence improve continuity in training and performance.

Supplementary Materials: The following are available online at https:/ /www.mdpi.com/1660-460 1/18/3/880/s1, Table S1: surveys.

Author Contributions: Conceptualization. A.C.-B.; Data curation. A.C.-B. and P.L.-G.; Formal analysis. J.C.-G., A.V. and J.M.-A.; Investigation. J.M.-A.; Project administration. A.C.-B.; Software. P.L.-G.; Supervision. A.V., D.F.-L. and J.M.-A.; Writing-Original draft. A.C.-B., D.F.-L. and J.M.-A.; Writing-Review \& editing. A.C.-B., J.C.-G., A.V., P.L.-G. and J.M.-A. All authors have read and agreed to the published version of the manuscript.

Funding: The authors declare no funding sources.

Institutional Review Board Statement: The study was conducted according to the guidelines of the Declaration of Helsinki, and approved by the Ethics Committee of University of Deusto (ref. ETK13/18-19).

Informed Consent Statement: Informed consent was obtained from all subjects involved in the study.

Acknowledgments: The authors thank the athletes and research assistants involved in this research for their participation, enthusiasm and cooperation.

Conflicts of Interest: The authors declare no conflict of interest.

\section{References}

1. Waydia, S.E.; Woodacre, T. Paddle-boarding: Fun, New Sport or an Accident Waiting to Happen? Trauma Mon. 2016, 21, e19299. [CrossRef] [PubMed]

2. Schram, B.; Hing, W.; Climstein, M. Profiling the sport of stand-up paddle boarding. J. Sport. Sci. 2016, 34, 937-944. [CrossRef]

3. Schram, B.; Hing, W.; Climstein, M. Laboratory and field based assessment of maximal aerobic power of elite stand-up paddleboard athletes. Int. J. Sport Physiol. Perform. 2016, 11, 28-32. [CrossRef] [PubMed]

4. McArthur, K.; Jorgensen, D.; Climstein, M.; Furness, J. Epidemiology of Acute Injuries in Surfing: Type, Location, Mechanism, Severity, and Incidence: A Systematic Review. Sports 2020, 8, 25. [CrossRef] [PubMed]

5. Pikora, T.J.; Braham, R.; Mills, C. The epidemiology of injury among surfers, kite surfers and personal watercraft riders: Wind and waves. Med. Sport Sci. 2012, 58, 80-97.

6. Furness, J.; Olorunnife, O.; Schram, B.; Climstein, M.; Hing, W. Epidemiology of injuries in Stand-Up Paddle Boarding. Orthop. J. Sport Med. 2017, 5. [CrossRef]

7. Griffin, A.R.; Perriman, D.M.; Neeman, T.M.; Smith, P.N. Musculoskeletal Injury in Paddle Sport Athletes. Clin. J. Sport Med. 2020, 30, 67-75. [CrossRef]

8. Abraham, D.; Stepkovitch, N. The Hawkesbury Canoe Classic: Musculoskeletal injury surveillance and risk factors associated with marathon paddling. Wilderness Environ. Med. 2012, 23, 133-139. [CrossRef]

9. Kameyama, O.; Shibano, K.; Kawakita, H.; Ogawa, R.; Kumamoto, M. Medical check of competitive canoeists. J. Orthop. Sci. 1999, 4, 243-249. [CrossRef]

10. Wassinger, C.A.; Myers, J.B.; Sell, T.C.; Oyama, S.; Rubenstein, E.N.; Lephart, S.M. Scapulohumeral kinematic assessment of the forward kayak stroke in experienced whitewater kayakers. Sports Biomech. 2011, 10, 98-109. [CrossRef]

11. Lovell, G.; Lauder, M. Bilateral strength comparisons among injured and noninjured competitive flatwater kayakers. J. Sport Rehabil. 2001, 10, 3-10. [CrossRef]

12. Michael, J.S.; Rooney, K.B.; Smith, R.M. The dynamics of elite paddling on a kayak simulator. J. Sport Sci. 2012, 32, 661-668. [CrossRef] [PubMed]

13. Lopez Lopez, C.; Ribas, J. A biomechanical analysis of the wrist joint in kayak paddling: A dynamic model. Rev. Andal. Med. Del. Deport. 2009, 2, 102-107. 
14. Hagemann, G.; Rijke, A.M.; Mars, M. Shoulder pathoanatomy in marathon kayakers. Br. J. Sport Med. $2004,38,413-417$. [CrossRef] [PubMed]

15. Pelham, T.W.; Holt, L.E.; Stalker, R. The etiology of paddler's shoulder. Aust. J. Sci. Med. Sport 1995, $27,43-47$.

16. Worrell, T.W.; Perrin, D.H. Hamstring muscle injury: The influence of strength, flexibility, warm-up, and fatigue. J. Orthop. Sport Phys. Ther. 1992, 16, 12-18. [CrossRef] [PubMed]

17. Ingraham, S.J. The role of flexibility in injury prevention and athletic performance: Have we stretched the truth? Minn. Med. 2003, 86, 58-61.

18. Gleim, G.W.; McHugh, M.P. Flexibility and its effects on sports injury and performance. Sports Med. 1997, 24, 289-299. [CrossRef]

19. Bagherian, S.; Ghasempoor, K.; Rahnama, N.; Wikstrom, E.A. The Effect of Core Stability Training on Functional Movement Patterns in College Athletes. J. Sport Rehabil. 2019, 18, 444-449. [CrossRef]

20. Araujo, S.; Cohen, D.; Hayes, L.D. Six weeks of core stability training improves landing kinetics among female capoeira athletes: A pilot study. J. Hum. Kinet. 2015, 45, 27-37. [CrossRef]

21. Peate, W.F.; Bates, G.; Lunda, K.; Francis, S.; Bellamy, K. Core strength: A new model for injury prediction and prevention J. Occup. Med. Toxicol. 2007, 2, 3. [CrossRef] [PubMed]

22. Batalha, N.; Paixão, C.; Silva, A.J.; Costa, M.J.; Mullen, J.; Barbosa, T.M. The Effectiveness of a Dry-Land Shoulder Rotators Strength Training Program in Injury Prevention in Competitive Swimmers. J. Hum. Kinet. 2020, 31, 11-20. [CrossRef] [PubMed]

23. Lehnert, P.; Sigmund, M.; Lipinska, P.; Vařeková, R.; Hroch, M.; Xaverová, Z.; Stastny, P.; Háp, P.; Zmijewski, P. Training-induced changes in physical performance can be achieved without body mass reduction after eight week of strength and injury prevention oriented programme in volleyball female players. Biol. Sport 2017, 34, 205-213. [CrossRef] [PubMed]

24. Baltich, J.; Emery, C.; Stefanyshyn, D.; Nigg, B.M. The effects of isolated ankle strengthening and functional balance training on strength, running mechanics, postural control and injury prevention in novice runners: Design of a randomized controlled trial. BMC Musculoskelet Disord. 2014, 15, 407. [CrossRef] [PubMed]

25. Askling, C.; Karlsson, J.; Thorstensson, A. Hamstring injury occurrence in elite soccer players after preseason strength training with eccentric overload. Scand. J. Med. Sci. Sports 2003, 13, 244-250. [CrossRef] [PubMed]

26. Worrell, T.W.; Perrin, D.H.; Gansneder, B.M.; Gieck, J.H. Comparison of isokinetic strength and flexibility measures between hamstring injured and noninjured athletes. J. Orthop. Sports Phys. Ther. 1991, 13, 118-125. [CrossRef] [PubMed]

27. Boström, A.; Thulin, K.; Fredriksson, M.; Reese, D.; Rockborn, P.; Hammar, M. Risk factors for acute and overuse sport injuries in Swedish children 11 to 15 years old: What about resistance training with weights? Scand. J. Med. Sci. Sports 2016, 26, 317-323. [CrossRef] [PubMed]

28. Fleck, S.J.; Falkel, J.E. Value of Resistance Training for the Reduction of Sports Injuries. Sports Med. 1986, 3, 61-68. [CrossRef]

29. Ribeiro-Alvares, J.B.; Marques, V.B.; Vaz, M.A.; Baroni, B.M. Four Weeks of Nordic Hamstring Exercise Reduce Muscle Injury Risk Factors in Young Adults. J. Strength Cond. Res. 2018, 32, 1254-1262. [CrossRef]

30. Coppack, R.J.; Etherington, J.; Wills, A.K. The effects of exercise for the prevention of overuse anterior knee pain: A randomized controlled trial. Am. J. Sports Med. 2011, 39, 940-948. [CrossRef]

31. Zouita, S.; Zouita, A.B.M.; Kebsi, W.; Dupont, G.; Ben Abderrahman, A.; Ben Salah, F.Z.; Zouhal, H. Strength Training Reduces Injury Rate in Elite Young Soccer Players During One Season. J. Strength Cond. Res. 2016, 30, 1295-1307. [CrossRef] [PubMed]

32. O'Toole, M.L. Prevention and treatment of injuries to runners. Med. Sci. Sports Exerc. 1992, 24, S360-S363. [CrossRef] [PubMed]

33. Drew, M.K.; Raysmith, B.P.; Charlton, P.C. Injuries impair the chance of successful performance by sportspeople: A systematic review. Br. J. Sports Med. 2017, 51, 1209-1214. [CrossRef] [PubMed]

34. Hamill, B. Relative safety of weightlifting and weight training. J. Strength Cond. Res. 1994, 8, 53-57.

35. Fortaleza World Medical Association declaration of Helsinki: Ethical principles for medical research involving human subjects. J. Am. Med. Assoc. 2013, 2191-2194.

36. Kottow, M. From Helsinki to Fortaleza: A bled declaration. Rev. Bioét. 2014, 22. [CrossRef]

37. Ferguson, C. An Effect Size Primer: A Guide for Clinicians and Researchers. Prof. Psychol. Res. Pract. 2009, 40, 532-538. [CrossRef]

38. Dill, K.E.; Begalle, R.L.; Frank, B.S.; Zinder, S.M.; Padua, D.A. Altered knee and ankle kinematics during squatting in those with limited weight-bearing-lunge ankle-dorsiflexion range of motion. J. Athl. Train. 2014, 49, 723-732. [CrossRef]

39. Fong, C.M.; Blackburn, J.T.; Norcross, M.F.; McGrath, M.; Padua, D.A. Ankledorsiflexion range of motion and landing biomechanics. J. Athl. Train. 2011, 46, 5-10. [CrossRef]

40. Fousekis, K.; Tsepis, E.; Poulmedis, P.; Athanasopoulos, S.; Vagenas, G. Intrinsic risk factors of non-contact quadriceps and hamstring strains in soccer: A prospective study of 100 professional players. Br. J. Sports Med. 2011, 45, 709-714. [CrossRef]

41. Craib, M.W.; Mitchell, V.A.; Fields, K.B.; Cooper, T.R.; Hopewell, R.; Morgan, D.W. The association between flexibility and running economy in sub-elite male distance runners. Med. Sci. Sports Exerc. 1996, 28, 737-743. [CrossRef] [PubMed]

42. Steib, S.; Rahlf, A.L.; Pfeifer, K.; Zech, A. Dose-Response Relationship of Neuromuscular Training for Injury Prevention in Youth Athletes: A Meta-Analysis. Front. Physiol. 2017, 8, 920. [CrossRef] [PubMed]

43. Mandelbaum, B.R.; Silvers, H.J.; Watanabe, D.S.; Knarr, J.F.; Thomas, S.D.; Griffin, L.Y.; Kirkendall, D.T.; Garrett, W. Effectiveness of a Neuromuscular and Proprioceptive Training Program in Preventing the Incidence of Anterior Cruciate Ligament Injuries in Female Athletes: 2-year follow up. Am. J. Sports Med. 2005, 33, 1-8. [CrossRef] [PubMed]

44. Kiani, A.; Hellquist, E.; Ahlqvist, K.; Gedeborg, R.; Michaëlsson, K.; Byberg, L. Prevention of soccer-related knee injuries in teenaged girls. Arch. Intern. Med. 2010, 170, 43-49. [CrossRef] [PubMed] 
45. Waldén, M.; Atroshi, I.; Magnusson, H.; Wagner, P.; Hägglund, M. Prevention of acute knee injuries in adolescent female football players: Cluster randomised controlled trial. BMJ 2012, 344, 1-11. [CrossRef]

46. LaBella, C.R.; Huxford, M.R.; Grissom, J.; Kim, K.-Y.; Peng, J.; Christoffel, K.K. Effect of Neuromuscular Warm-up on Injuries in Female Soccer and Basketball Athletes in Urban Public High Schools: Cluster Randomized Controlled Trial. Arch. Pediatr. Adolesc. Med. 2011, 165, 1033-1040. [CrossRef]

47. DeFreitas, J.M.; Beck, T.W.; Stock, M.S.; Dillon, M.A.; Kasishke, P.R. An examination of the time course of training-induced skeletal muscle hypertrophy. Eur. J. Appl. Physiol. 2011, 111, 2785-2790. [CrossRef]

48. Brook, M.S.; Wilkinson, D.J.; Mitchell, W.K.; Lund, J.N.; Szewczyk, N.J.; Greenhaff, P.L.; Smith, K.; Atherton, P.J. Skeletal muscle hypertrophy adaptations predominate in the early stages of resistance exercise training, matching deuterium oxide-derived measures of muscle protein synthesis and mechanistic target of rapamycin complex 1 signaling. FASEB J. 2015, 29, 4485-4496. [CrossRef]

49. Damas, F.; Phillips, S.M.; Lixandrao, M.E.; Vechin, F.C.; Libardi, C.A.; Roschel, H.; Tricoli, V.; Ugrinowitsch, C. Early resistance training-induced increases in muscle cross-sectional area are concomitant with edema-induced muscle swelling. Eur. J. Appl. Physiol. 2016, 116, 49-56. [CrossRef]

50. Sale, D.G. Neural adaptation to resistance training. Med. Sci. Sports Exerc. 1988, 20, 135-145. [CrossRef]

51. Pfile, K.R.; Hart, J.M.; Herman, D.C.; Hertel, J.; Kerrigan, D.C.; Ingersoll, C.D. Different exercise training interventions and drop-landing biomechanics in high school female athletes. J. Athl. Train. 2013, 48, 450-462. [CrossRef] [PubMed]

52. Celebrini, R.G.; Eng, J.J.; Miller, W.C.; Ekegren, C.L.; Johnston, J.D.; MacIntyre, D.L. The effect of a novel movement strategy in decreasing ACL risk factors in female adolescent soccer players. J. Strength Cond. Res. 2010, 26, 3406-3417. [CrossRef] [PubMed]

53. Lauersen, J.B.; Andersen, T.E.; Andersen, L.B. Strength training as superior, dose-dependent and safe prevention of acute and overuse sports injuries: A systematic review, qualitative analysis and meta-analysis. Br. J. Sports Med. 2018, 52, $1557-1563$. [CrossRef] [PubMed]

54. Lehman, G. Resistance training for performance and injury prevention in golf. J. Can. Chiropr. Assoc. 2006, 50, 27-42. [PubMed]

55. Shaw, I.S.; Shaw, B.A.; Brown, G.; Shariat, A. Review of the Role of Resistance Training and Musculoskeletal Injury Prevention and Rehabilitation. J. Orthop. Res. Ther. 2016, 1. [CrossRef]

56. Kubo, K.; Kanehisa, H.; Miyatani, M.; Tachi, M.; Fukunaga, T. Effect of low-load resistance training on the tendon properties in middle-aged and elderly women. Acta Physiol. Scand. 2003, 178, 25-32. [CrossRef]

57. Langberg, H.; Ellingsgaard, H.; Madsen, T.; Jansson, J.; Magnusson, S.P.; Aagaard, P.; Kjær, M. Eccentric rehabilitation exercise increases peritendinous type I collagen synthesis in humans with Achilles tendinosis. Scand. J. Med. Sci. Sports 2007, 17, 61-66. [CrossRef]

58. Lorenz, D.; Reiman, M. The role and implementation of eccentric training in athletic rehabilitation: Tendinopathy, hamstring strains, and acl reconstruction. Int. J. Sports Phys. Ther. 2011, 6, 27-44.

59. Hoffman, J. Resistance Training and Injury Prevention. Available online: https:/ /www.acsm.org/docs/default-source/files-forresource-library/smb-resistance-training-and-injury-prevention.pdf (accessed on 15 December 2016).

60. Häkkinen, K.; Kallinen, M.; Izquierdo, M.; Jokelainen, K.; Lassila, H.; Mälkiä, E.; Kraemer, W.; Newton, R.; Alen, M. Changes in agonist-antagonist EMG, muscle CSA, and force during strength training in middle-aged and older people. J. Appl. Physiol. 1998, 84, 1341-1349. [CrossRef]

61. Wernbom, M.; Augustsson, J.; Thomeé, R. The influence of frequency, intensity, volume and mode of strength training on whole muscle cross-sectional area in humans. Sports Med. 2007, 37, 225-264. [CrossRef]

62. Jones, D.; Rutherford, O.; Parker, D. Physiological changes in skeletal muscle as a result of strength training. Q. J. Exp. Physiol. 1989, 74, 233-256. [CrossRef] [PubMed]

63. Staron, R.; Malicky, E.; Leonardi, M.; Falkel, J.; Hagerman, F.; Dudley, G. Muscle hypertrophy and fast fiber type conversions in heavy resistance-trained women. Eur. J. Appl. Physiol. Occup. Physiol. 1990, 60, 71-79. [CrossRef] [PubMed]

64. Bouchard, C.; Rankinen, T.; Timmons, J.A. Genomics and genetics in the biology of adaptation to exercise. Compr. Physiol. 2011, 1, 1603-1648. [PubMed]

65. Petrella, J.K.; Kim, J.S.; Mayhew, D.L.; Cross, J.M.; Bamman, M.M. Potent myofiber hypertrophy during resistance training in humans is associated with satellite cell-mediated myonuclear addition: A cluster analysis. J. Appl. Physiol. 2008, 104, 1736-1742. [CrossRef]

66. Shaw, G.; Lee-Barthel, A.; Ross, M.L.; Wang, B.; Baar, K. Vitamin C-enriched gelatin supplementation before intermittent activity augments collagen synthesis. Am. J. Clin. Nutr. 2017, 105, 136-143. [CrossRef]

67. Bosmans, L.; Valente, G.; Wesseling, M.; Van Campen, A.; De Groote, F.; De Schutter, J.; Jonkers, I. Sensitivity of predicted muscle forces during gait to anatomical variability in musculotendon geometry. J. Biomech. 2015, 48, 2116-2123. [CrossRef]

68. Faigenbaum, A.D.; Myer, G. Resistance training among young athletes: Safety, efficacy and injury prevention effects. Br. J. Sports Med. 2010, 44, 56-63. [CrossRef]

69. Myer, G.D.; Faigenbaum, A.D.; Ford, K.R.; Best, T.M.; Bergeron, M.F.; Hewett, T.E. When to initiate integrative neuromuscular training to reduce sports-related injuries and enhance health in youth? Curr. Sports Med. Rep. 2011, 10, 155-166. [CrossRef]

70. Hartmann, H.; Wirth, K.; Keiner, M.; Mickel, C.; Sander, A.; Szilvas, E. Short-term periodization models: Effects on strength and speed-strength performance. Sports Med. 2015, 45, 1373-1386. [CrossRef] 
71. Calleja-González, J.; Mielgo-Ayuso, J.; Sampaio, J.; Delextrat, A.; Ostojic, S.M.; Marques-Jiménez, D.; Arratibel, I.; Sánchez-Ureña, B.; Dupont, G.; Schelling, X.; et al. Brief ideas about evidence-based recovery in team sports. J. Exerc. Rehabil. 2018, 14, 545-550. [CrossRef]

72. Blagrove, R.C.; Howatson, G.; Hayes, P. Effects of Strength Training on the Physiological Determinants of Middle- and LongDistance Running Performance: A Systematic Review. Sports Med. 2018, 48, 1117-1149. [CrossRef] [PubMed]

73. Zemková, E. Instability resistance training for health and performance. J. Tradit. Complement. Med. 2016, 7, 245-250. [CrossRef] [PubMed]

74. Rössler, R.; Junge, A.; Chomiak, J.; Dvorak, J.; Faude, O. Soccer Injuries in Players Aged 7 to 12 Years: A Descriptive Epidemiological Study Over 2 Seasons. Am. J. Sports Med. 2016, 44, 309-317. [CrossRef] [PubMed]

75. Ueberschär, O.; Fleckenstein, D.; Warschun, F.; Kränzler, S.; Nico Walter, M.W.H. Measuring biomechanical loads and asymmetries in junior elite long-distance runners through triaxial inertial sensors. Sports Orthop. Traumatol. 2019, 35, 296-308. [CrossRef]

76. Alfonso, J.; Bessa, C.; Pinto, F.; Ribeiro, D.; Moura, B.; Rocha, T.; Vinícius, M.; Canário-Lemos, R.; Peixoto, R.; Clemente, F.M. Asymmetries in Daily Activities. In Asymmetry as a Foundational and Functional Requirement in Human Movement; Springer: Singapore, 2020; pp. 17-20. 